\title{
Power, Pleasure, and Play
}

\section{Screwing the Dildo and Rescripting Sexual Violence}

Jeanine Minge, $\mathrm{PhD}$

University of California, Northridge

Amber Lynn Zimmerman, $\mathrm{PhD}$

University of Waterloo, Ontario, Canada

\begin{abstract}
This article centers on the renaming of violent sex narratives through the resignification of penetration and the dildo. The dominant sex narrative in much of our cultural conversation is one rooted in heteronormativity. Additionally, the dominant narrative often eclipses the importance of sex as intimate ground in which people share knowledge of the body - the body being a complex site of personal perception and social interpellation. Bricolage as a method operates as a helpful conduit in revealing this complexity, as it allows for multiplicity of construction and meaning. By intertwining theory and method from various disciplinary perspectives, a rich text emerges full of questions, possibilities, and agency.
\end{abstract}

Keywords: Bricolage, Resignification, Feminism, Sex

Definition: Rape $^{1}$

Penetration with the use of force and without the person's consent. Penetration can be with the penis or other instruments like bottles or sticks, and can be penetrated in the vagina, anus, or mouth.

\section{Penetration: Germany, 1999}

$\mathrm{D}$

irty against the floor, against the mattress of some stranger's bed.

\footnotetext{
Authors' Note: This piece contains explicit sexual material. It may be considered obscene. If you discount the importance of rape narratives, are offended by queer sex or raw language, do not read any further. This piece writes into what is often left silent in the academic realm. Please address correspondence to Jeanine Minge, Manzanita Hall, Room 220, Northridge, CA 91330-8257; e-mail: jeanine.minge@ gmail.com.
} 
I cocoon myself in the blankets and try to close my eyes. If I sleep, this will be over faster and he'll leave me alone. shit shit shit. Think happy thoughts. Shit shit shit. fuck. I shiver and toss and turn. Shit shit shhhhhh. I don't remember falling asleep. I do remember waking up with a face and finger in my crotch. Penetrated by his lips, his tongue, his fingers. He looks up and notices I am awake. He moves quickly and slides up my body, pushes his dick inside. He scrapes my walls.

I can feel this now as I write this, so clearly. I can feel him moving up inside me. I hear him slide outside of me. Penetrated.

I scream once, then feel his hand over my lips. I will never forget him asking, "What's your fantasy?" with his lips huffing in my ear. I stay silent and sob while he continues, "Mine is two guys and a woman. I want to sit in a corner and watch him pound into you."

Hump heave. My insides fall in. I want to scream. His hand keeps me silent, muffled in my pain. Please get the fuck off me you sick bastard. Hump heave. Hump heave. The mattress groans, squeaks. Then . . silence, only silence except for his thick breath. I can feel his sweat slide over my thigh. He pulls out of my vagina. I'm aching and sore. I close my eyes and inhale deep breaths. My legs are wet with this strange and eerie cum.

\section{Unscrewing Screwed Discourse}

My body holds the traumatic memory of heterosexual rape. I was raped once by my male teenage crush when I was 17 , and then again by a different man at 22. My body knows and has felt traumatic penetrations. It has been almost 6 years since my last rape experience. I wrote about these rape experiences a year ago Minge, J. M. (2007). The stained body: A fusion of embodied art on rape and love. Journal of Contemporary Ethnography, 36, 252-280. My rape experiences are in print for readers to experience themselves. I wrote,

I have not been able to trust the body against mine. I have trained myself to disconnect from any physical contact. I have not been able to kindly hold any sexual body. In all of my sexual interactions, with men or women, I have held emotion at a distance. In most of my sexual interactions, I have to talk myself back into the moment. I have had to tell myself to remain in the body. I also have felt my body resist such a request. I have had intense flashbacks. I have felt incredible fear gripping at my throat. During sex, I have felt suffocated, claustrophobic, panicked. "Once experiencing is underway, the survivor lacks authority to stop it or put it away. The helplessness associated with the original experience is replayed by the apparent helplessness to end or 
modify the re-experience once it has begun" (Shay, 1994, p. 174). This has played out in my body's inability to find comfort in a sexual experience. In most sexual encounters, I freeze (Minge, 2007).

Assault is not all I have experienced sexually. My body has also known and understood pleasurable penetrations. As a woman with a fluid sexual identity, I have had sexual encounters with men and women. I have been a part of mediocre sexual relationships, and I have had titillating sex. In all the variations of these sexual relationships, I can't seem to get away from the physical, emotional, social, and political repercussions of sexual violence. It hasn't been until recently that I have been able to understand sex as pleasurable. The dildo has been part of this newfound pleasure. I use the dildo as a tool for discursively and physically rescripting what I once understood as violent penetration. I now understand that penetration is desire passed between, into, through, and with bodies.

Prior to this newfound pleasurable form of penetration with the dildo, my sexual life was understood through a heteronormative frame. Although not all heterosexual sexual acts are violent, uninviting, or painful, I engaged my heterosexual sexual life for the other. I was taught about pleasure and pain through teenage conversations, cinematic representations, and romantic fantasy novels. I learned quite quickly how to give up my agency to a man's desire, even if I did not enjoy it. In my teens and early 20 s, I quickly learned how powerfully violent unauthorized male penetration could be. At the same time, I found penetrative acts with other women and men to be exciting, exhilarating, and frightening. Now, in my late 20s, I have devoured the dildo. I reframe penetration. What was once a violent act inscribed onto my passive body is now entering into my body as agent between desiring bodies. And yet, the discourses that surround me and my sexual choices remain violent. I write to make sense of and understand my dildonic sexual life, in my own terms, in my own politicized vagina. The dildo is a symbol devoured with or without acknowledged meaning, an object that can create personal ecstasy and political transformation.

In this essay, I explore the reign of the dildo in my life by presenting the dildo's history, feminist controversy surrounding the dildo in the sex wars, and a gender theory approach to the dildo. I use personal narratives of penetration, both violent and ecstatic. Threaded within these three explorations, I use six definitions of penetration to frame the variety of ways we can conceptualize penetrative acts. First, I detail the methodological frame for this work. Next, I move into a rape experience contextually, bound by my understanding of penetration as violent and shameful. Then, I write of the day I bought my first dildo and began to learn about my own sexual 
agency. Following this, I share my first sexual encounter with a woman where I discovered that memories of sexual violence penetrate just as violently as that penis did. Finally, in a sexual moment with my lover, I find the dildo can offer a full sense of sexual agency. In this context, the dildo is a rebirthing tool for my sexual prowess. I am once again sexually alive.

\section{Methodological Note}

I engage cultural studies, feminism, queer theory, rhetorical criticism, and autoethnography in this article as a direct response to Denzin and Lincoln's (2000) call to present a variety of methodological perspectives as a practice of responsible scholarship. Core to the art of bricolage is revealing etymological influence to capture the seed of our social constructions (Kincheloe, 2001). My multiple definitions of penetration and the symbolically weighted use of the dildo in this article are direct choices so we may begin to understand social constructions of penetration.

Bricolage is "the processes by which elements are appropriated from the dominant culture, and their meaning transformed ... to challenge and subvert that culture" (Edgar \& Sedgwick, 1999, p. 48). Bricolage then, in its expansive possibility, allows the writer to create something new out of olds parts. I write here about the reclamation of sexuality and the resignification of contentious terms by collecting pieces of cultural junk and making something useful out them. In this way, the bricoleur becomes a strategic magician who puts scraps of pain and confusion into her hat to then pull out a narrative of hope.

Rich (2001) also writes about the importance of creative play in resignification:

You have to be free to play around with the notion that day might be night, love might be hate; nothing can be too sacred for the imagination to turn into it opposite or to call experimentally by another name. For writing is re-naming. (p. 21)

In qualitative research, we rename the world as we write. Many of us as scholars, rename the world because we are inspired to transform the cultural contexts we live within to foster deeper relationships, stronger communities, and a wider platform for dialogue to occur. This article champions such ideals through the use of bricolage. By allowing the imagination to run wild with theoretical and experiential desire, I capture a human process of memory, particularly when trying to re-member the self after experiencing violence. 
Writing about the experience of violence, and the process of moving through it, is a form of empowerment. Although it is sometimes difficult to write about and witness violence, the act of sharing such pain creates a mutual consciousness-raising. As modeled by feminists since the 1970s, consciousness-raising is a process by which exploitation and oppression is realistically discussed so that people can both heal and challenge the forces of patriarchy (hooks, 2000). Chodron (2006) emphasizes that a key aspect of healing is to ask:

Can I touch the center of my pain? Can I sit with suffering, both yours and mine, without trying to make it go away? Can I stay present to the ache of loss or disgrace — disappointment in all its many forms — and let it open me? (p. 69)

To write into the center of these questions is an act of vulnerability, and the practice of vulnerability in all its risk, has the potential to invite others into healing as well. Healing takes many forms. I write my fear, my pain, and my bravery in a way that does not sugarcoat my raw experience. In this text, I freely use obscene language, not as a careless affront, but as a way to ironically juxtapose polished theory with raw lexicon in an effort to reveal cultural slippage. If I were to euphemize or sanitize the language of my memory, I would be participating in a level of social silence that I'm not willing to engage. People talk about sex and desire obscenely. It is a cultural artifact.

Writing is a tool for solving the mystery of cultural artifacts and meanings. Richardson (2000) states, "I write because I want to find something out. I write in order to learn something that I did not know before I wrote it" (p. 97). Writing as methodological inquiry represents reality so that we can engage in cultural dialogue and identify the similarities and differences among symbolically constructed experiences. Tillman-Healy (1996) uses narrative to address her battles with bulimia. She states, "I take the emotional/professional risk of sharing the darkest most painful secret of my life in order to expose some of the lived, felt consequences of these stories and to open dialogues aimed at writing new and better ones" (pp. 80-81). The autoethnographic narrative is a space to open new pathways. It invites the reader to write back, to take in new understanding, to take on new perspectives and engage in their own relocation.

Certainly, I could write about penetration and reclamation in a way that gets straight to the point with no regard for nuance or foreplay. I could penetrate these pages with forced intent, thrusting out words that reiterate over and over and over the damage of phallic narratives of power, rape, and masculinity without bothering to consider multiple perspectives. I could focus 
on the orgasmic goal of an unmistakable theoretical truth, to pull you into my narrative and then out again in a clear ejaculation of ideas. Simple. Efficient. Wrote. Obviously, there are times and places for narratives of simplicity. This article is not one of those places. This article unabashedly lays out the body in raw vulnerability. My body, my pain, and my desire spread across the page for you to enter. I ask you, dear reader, to be a partner I can trust with my body. Encounter this work like you would a lover you adore. My body is trying to tell your body something in hopes that we can both find sexual fulfillment apart from violent constructs.

\section{A Dildo's History: Whose Penis Is It Anyway?}

Historically, meanings ascribed to the dildo were couched in heterosexual discourse. The following three examples of the dildo in sexual history frame the dildo as a phallic representation giving women pleasure. The woman's agency in this heterosexual frame is thereby eradicated or subordinated beneath the power of phallus, signified or "Real." Although there are records and pictures of phallic symbols throughout history, it was not until the early mid-1800s that the dildo appeared, quite openly, as a viable sexual tool. It first appeared as a valid medical device to protect women, as a benefit to men, from hysteria. Hysteria's symptoms were irritability, excessive vaginal fluids, heavy uterus, and fantasies. Hysterical women were often frustrated in their sexual release. The cure was in the physician's hands, quite literally. The physician would massage his patient's clitoris until "paroxysm," otherwise know as orgasm, was achieved. The doctor believed he had the authority and power to assuage a woman's sexual urges or desires. He would often dispense a phallus shaped apparatus as a therapeutic device (Maines, 1999).

In an interesting Forbes magazine article, scholar Nathaniel Philbrick retells the important discovery of Chinese dildos called "he's-at-homes" (Condgon, 1997). According to Philbrick, Nantucket whalers during the 18th and 19th centuries brought these devices home for their wives. It is speculated that the whaler's wives wouldn't commit adultery while they were at sea because they would keep themselves satisfied with the "stand in man" (Congdon, 1997). According to Potts (2000), "In Western culture there exists a syncedotal relationship between the man and his penis" (p. 85). With the men away at sea, the dildo acted as the stand-in man to ensure fidelity.

In the earlier part of the 20th century, dildos and vibrators began to make their appearance in women's magazines and catalogues as a device to 
relieve anxiety and female tension. Sold through Sears Roebuck, these toys were described as aids that every woman would love (Maines, 1999). The "he's-at-homes" use was encouraged as a way to keep women relaxed and content with a representation of the male sex organ that was "naturally" designed to fill the woman's void.

The constitution of women's bodies as lacking engenders the view that the penis is performer, completer, or filler of the void (Potts, 2000). This perspective casts the male as active within heterosexual sex acts and the woman as the passive recipient. According to Grosz (1989), "The symbolic function of the phallus envelops the penis as the tangible sign of a privileged masculinity, thus in effect naturalizing male dominance" (p. 123). This male dominance in heteronormative sexuality points toward a long history of heteroviolence and power over the woman. The sexual act, however, does not only occur at the level of signification. The sex act also occurs in between and through "real" bodies.

The dildo is part of larger cultural discourses concerning bodies, power, violence, and a plethora of sexual identities. There are many questions surrounding the use of the dildo: Is the power of the dildo, as a symbol of the phallus, in the hands of those who wield it? Does this power include resignification or is the dildo just another tool to reinscribe heteronormative sexual behavior?

\section{Through the Flesh: Fragmented Pieces of Penetration}

\section{Definition 1: Penetration ${ }^{2}$}

The act (by a man) of inserting his penis into the vagina of a woman

I "google" penetration and I find a scope of definitions. A gritty image of a woman on her knees being fucked from behind pops up on the screen. The man doesn't have a face. He is a disembodied image of his penis. Next image: A penis ejaculates on a woman's face. The woman's eyes look straight into the camera. Submission/domination. Domination/submission. Next image: A woman is on the floor. She is contoured in some strange position. At this angle, the woman is only her vagina. She is a port of entry. I squirm. It is really uncomfortable for me to look closely, to stare for longer than a second. I know violent penetrative acts in heterosexual circumstances, and these images flirt with my memories. These kinds of images don't conjure up memories of sexualized encounters that resonate agency and respect. At least, not to me, they don't. Rather, they fulfill a hypermasculine fantasy rooted in domination, control, and pillage. I feel guilty for looking too long at these images and close the Internet browser. 
I even go so far as to clear my Internet history. I feel dirty and ashamed. I feel implicated. I feel aroused.

This arousal marks an important distinction for me. I am turned on by these images. I am also angry, disgusted at my bodily reaction. I am uncomfortable, trying to reconcile my visceral reactions of the past with my current conversation with the computer screen. I wonder if the reader is just as uncomfortable with the images that I recreate for them here? I wonder if the reader feels implicated, aroused? It's difficult to reconcile past wounds, sexually violent sociocultural norms, and the need to express myself sexually. Is it appropriate to be turned on by the same dominating images that have manifested themselves in my sexual history? Should I see the phallic image as my enemy? Should I hide from these urges, these images? Should I write about them now? I don't want to hide from these difficult discussions. I will not hide from the pain, the sexual tension, or the arousal. Feminist scholars engaged in the sex wars/debates of the 1970s have also found it difficult to reconcile such issues.

\section{The Sex Wars: Feminists and the Dildo}

The sex wars/debates of the 1970s opened a big can of lube, and when considering the dildo, I find very little resolve in these debates. On one side of the lesbian/feminist sex wars stand those lesbians who reject the dildo as a discursive and symbolic function of heterosexuality. To scholars such as Mackinnon (1986), Rich, A. (1980). The dream of a common language. New York: W. W. Norton, and Johnston (1973), the dildo only magnifies hypermasculine, heteronormative sexuality. On the other side of the debate rests those lesbian feminists, the sex outlaws, who see the dildo as a sex toy, a strong material to fill an orifice and create pleasure, which thereby subverts masculine power.

\section{Radical Lesbian Feminists: The Dildo Is Our Enemy}

In 1973, Jill Johnston published a book titled, Lesbian Nation. Johnston's work scolded feminists, claiming that they were too posh, heterosexist, and high strung to understand the way lesbians play a role within feminist identities. In a bold move, Johnston (1973) stated, "It's impossible to separate our oppression as women from our oppression as lesbians. All women are lesbians" (p. 90). She saw women who bed with men as obtaining sexual gratification from their institutional oppressor, whereas the lesbian was fusing the personal and the political. She stated, 
The lesbian argument is first and foremost withdrawal at every level from the man to develop woman supremacy . . . the (re) development of the moral physical spiritual intellectual strengths of women whatever the social consequences of that may be. (p. 276)

Because of the discrimination she felt from the second-wave feminists, Johnston called for a separatist and radical lesbian politic, one that acknowledged the choice of mate as a highly political choice. Johnston's radical lesbian feminist politic spawned a new debate, one centered on the sexual acts of feminists.

In 1980, Adrienne Rich argued that the enforcement of heterosexuality keeps women trapped within the confines of patriarchy. Women are thereby constantly terrorized by "woman-hatred which is embedded in maledominated culture, to the forms assumed by normal male sexuality" (p.127). Male power denies women their sexuality, and sexuality is thereby forced on them. One way in which heterosexuality is forced on women is through pornography. Pornographic films are created through the male gaze, which is devoid of emotion or individual personality. Rich (1984) stated, "The most pernicious message relayed by pornography is that women are natural sexual prey to men and love it; that sexuality and violence are congruent; and that for women sex is essentially masochistic, humiliation pleasurable, physical abuse erotic" (p. 127). Within heterosexual pornographic films, the dildo is used by men to penetrate women vaginally, orally, and anally. Within lesbian pornographic films, the dildo is used by women to penetrate in the same heterosexist manner.

Antipornography feminists, such as Mackinnon (1986) and Dworkin (1981) stated that pornography was inherently misogynist. Pornography ultimately linked violence and death with normative heterosexuality. Pornography taught men that women were objects to be used for sexual encounters, violently and shamelessly (Kennedy, 2000). Compulsory heterosexuality was everywhere (Rich, 1980). And to get out of this violent patriarchal structure, women needed to create their own master narrative, a larger claim to women's experiences through identification with other women. Rich (1984) as a "Women-Identified Woman" argued that women need to see women-identification as a source of empowerment, to change the social relations of the sexes, and to "undo the power men everywhere wield over women, power which has become a model for every other form of exploitation and illegitimate control" (p. 144).

One way to escape the clutches of the heterosexist patriarch is to reframe how we make love, fuck, have sex. Smith (2002) states, "The lesbian feminist texts I was reading at the time denounced penetration as a symbol of heterosexism and recommended recentering sex around intense intimacy cultivated 
between two women" (pp. 294-295). "Good" lesbian feminists knew that orgasm from vaginal penetration was a myth. They knew that dildos and roleplay were forbidden. They knew and understood that women connected to each other differently, and that they needed to have sex apart from men.

To radical lesbian feminists, heterosexuality is the dominant frame through which we understand sexual acts and more exclusively, the lesbian sex act. Accordingly, the dildo, the most phallic of symbols, is a sex toy recreating male-dominated heterosexuality within lesbian relationships. "Because dildos are typically fashioned after the penis and are used for one of the same purposes - penetrating a woman's body - they are also considered a phallic tool, very powerfully and potentially hurtful" (Smith, 2002, p. 296). The dildo creates and recreates the heterosexual assumption that men have power over women in the bedroom. The dildo is one source/ cultural representation of this hegemonic control. Lesbians did not need, and should not want, to engage in a sexual act with a strap-on. Political purity was more important than sexual desires (Kennedy, 2000). To be a "true" lesbian then you had to act like one sexually, culturally, privately, and politically. Intimacy and emotional connections between women were said to be more important than the act of sex (Smith, 2002). And using dildos, especially lifelike ones, was incompatible with woman-identified sexuality (Findlay, 2001). Not all feminist/lesbian/ women/queer/transbodies agree with such pointed critique of the dildo.

\section{Definition 2: Penetration ${ }^{3}$}

An attack that penetrates into enemy territory

\section{First Sexual Experience With a Woman: Fingers Inside}

My heart is beating too fast. Fingers, soft fingers lightly move across the lips of my wet vagina. She teases me with one finger lingering at the entrance. This is my first time making love to a woman, shit. Wow. My hands move over her breasts. I'm so nervous I barely touch the nipple. I tell myself softly, "This is ok. This is my body and her body. Close. Hmmm."

Her fingers penetrate me softly. I close my legs around them.

Instantly, the fear rises into my throat and dries the walls, the wall of my throat, and the walls of my vagina. I'm dry, invoking the memory of his breath, his fingers, the scraping. This is a negotiation between lovers, memories, and definition. Her fingers are the penetrative flesh. They are not a man's penis. But the memory lingers. The memory becomes the penetration. 
Her fingers only remind me of the violence. My legs close hard and I push up on her body. She pulls out and lets me cry. I wish I could speak and tell her:

I'm entering into uncharted territory.

The memory of him lingers like an enemy of war.

He attacks suddenly and drives the phallic

memory of colonization

into my body and dries it.

The war for my body,

begins here.

I want it back.

\section{The Dildo Pleases Me: So "Get on My Back"}

On the other side of the debate were the prosex sexual outlaws. To this group of lesbians, the radical lesbian feminists were too narrow in their definitions of "good" lesbian sexual practice. The self-proclaimed sex outlaws said that they had a more truthful representation of the lesbian than the hegemonic lesbian feminist (Kennedy, 2000). Writers like Dorothy Allison (1994) wrote into the discussion a "true" representation of lesbian sexual acts as unapologetic, gritty, hard, and born out of violence and anger. To Allison and the other sexual outlaws, sexual expressions, such as the butch/femme script, pornography, and $\mathrm{s} / \mathrm{m}$ were not necessarily evil, but part of a lesbian's sexual reality. The sexual outlaws saw the women's movement as largely responsible for loss of desire and lust within lesbian political and sexual identity. To the outlaws, radical lesbian separatists like Rich and Dworkin, not only stripped lesbianism of desire in their quest to politicize sexual choice, but they also shamed those who didn't practice their brand of activism (Rubin, 1987).

In response to this politicized shame, they wrote about all the sexual taboos that they engaged in and enjoyed from the erotic, realist, and truthful tales that showed the world that lesbians had sexual desire and that women could make other women wet (Califa, 1988; Kennedy, 2000;). The sexual outlaws demonstrated quite vividly that lesbians used power in the bedroom to their own advantage. "The original heresy committed by the sexual outlaws was that they erotized the very value-power-that cultural feminism had set itself against. Power was put on display, ritualized, interrogated and ultimately fucked in the $\mathrm{s} / \mathrm{m}$ pornographic scene" (Kennedy, 2000). In the same moment, power relationships in the bedroom were playful, violent, and pleasurable. Sex toys, such as the dildo, were used and explained as part of lesbian sex acts used to subvert phallocentrism, through parodies of heteronormative behavior (Hamming, 2001). Sexual outlaws 
reassert this male power by claiming this power as their own. Masculine? Maybe. But in their "real" sex acts, lesbians have the power, thereby subverting heteronormative control. Here, the dildo is used to pleasure women in a variety of ways. The dildo was used to tantalize, slip into, fuck, penetrate, tease, and ultimately, to please women.

To defend this position, some lesbians (Bright, 1990; Nestle, 1987) have argued that dildos do not represent the penis. Instead, dildos have an authentic place in lesbian history. According to Findlay (1992),

In sum, as part of their challenge to what they see as the repressive sexual politics of radical feminism, Bright and other prosex feminists have defended the dildo by downplaying its referentiality, by denying that the dildo represents a penis." (p. 565)

Denying its connection to the penis downplays its connection to power, violence, and control over the woman's body.

\section{Definition 3: Penetration ${ }^{4}$}

The depth to which something penetrates (especially the depth reached by a projectile that hits a target)

I am intrigued by war metaphors. Sometimes I feel as though my body is at war with desire and traumatic memory. The depth to which the memory of rape penetrates my body is cavernous, strong; memory wrestles with my muscles and sinew. It has been 6 years now and his penetration hits the bone and rattles my sexual core. But I am a moving target. Moving targets are the most difficult to destroy.

\section{Buying My Own Agency: The Sex Shop}

Pamela's Secrets is a small house with a wrap around front porch converted into the only sex shop in Rockingham County, Virginia. Driving there in my beat-up Toyota Camry, I can feel my heart racing. I am going to buy a vibrator. I've never owned one before. I deserve one.

I wave to the woman at the front desk who sports blonde, poofy, mullet Virginia hair. She smiles and says "Hello" in her perfect southern drawl. I walk slowly around the bachelorette games pretending to shop for fake penis straws or a deck of boobie cards. Turing the corner, I see it, a hall of hanging cocks. It looks like a gigantic vagina corral. A man is in the corner looking at the back of one of the packages. I hear a swarm of giggles come from the other room. A pack of girls around my age or younger have entered the 
building. They laugh at the porn tapes. Giggles have a way of masking fear. But their presence makes me nervous. What if they see me? What if they know me? Whatever. Why should I care? They should get vibrators.

I keep my eyes on the dildos. There are way too many to choose from. I see silver bullets, long blue vibrators, "life size" versions of a man's penis with a vibrator inside, and the pink bunny. Wait. The pink bunny. I've heard of this before. Where? I don't know but I stop to take this box off the shelf. It is a massive vibrator/dildo with a huge pink shaft (that goes inside you), revolving beads (that move against your "G" spot), and a bunny head (that tickles your clit with its bunny ears). I'm feeling adventurous. I take the bunny home with me. The bunny and I stay acquainted for some time. She coaxes me. I move the bunny inside me at my own pace. This is the first time I hold the power of my own sexual satisfaction.

\section{A Third/Fourth Position: Trying to Resolve the Dildo}

The dildo wars or feminist sex wars necessarily cover and argue the distinctions between the phallus and its power over women and the power given to the phallic symbol. But these perspectives do not resolve ongoing debates about the dildo. Findlay (1992) argues that these debates are firmly planted within Freud's "fetishism," a concept astoundingly unkind to lesbians. Findlay argues that no matter how lesbian feminist's try, they are always situated within Freud's claim that "the fetish is a substitute for the woman's penis that the little boy once believed in and-for reasons familiar to us-does not want to give up" (p. 566). The dildo wars are about the symbolic link between the dildo and the phallus. In other words, women who use the dildo are still caught up in the juxtaposition of the castrated woman, Freud's fetishism, the myth of the mistaken desire for the phallus, and the guilty pleasure in dildo use.

Hamming (2001) reminds us that there is a fourth position to this debate, one that starts with Findlay's (1992), "Yes, but . . ." (p. 574). Hamming (2001) argues that the dildo does not signify “ . . . the lesbian's lack but rather offers evidence of her ability to disrupt the confines of gender by introducing this potentially rogue object into sexual identity performance" (p. 330). "The dildo moves from human to post-human" (p. 337), following Haraway's (1991) adoption of the provision and partial position of the cyborg to subvert and permeate the boundaries of patriarchal domination. Hamming's (2001) dildo as a cyborg offers gender flexibility by disconnecting it from its masculine history. It is a transformative object or prosthesis. The dildo does not run the risk of going soft or ejaculating too 
quickly. It is capable of "signifying an extra-phallic desire" (p. 331). She argues that the dildo scandalizes identity categories of gender and sexuality and should be recoded as a "postgender" neutral object. Such coding shifts the dildo from conventional gender transgression to gender mutation.

A conventional gender transgression turns the female body into a male body, which in turn, devalues the female body. Instead, reading the dildo as posthuman leads the reader to believe in the postlesbian. Citing Grosz (1994), Hamming (2001) suggests the postlesbian and her sexual acts are not about castration or the binary between presence and absence, but about machinic connections from one body to another. Here, in this fourth "unnatural" position, Hamming argues that in the postlesbian sex act, the woman is cyborg. Not male. Not castrated. She is a new creation. The dildo "allows both partners to operate in both sexual positions, blending the previously binary sexual roles of heterosexual sex, again, mutating the traditional narrative of heterosexuality, and one could argue, improving upon it" (p. 339). Moving out of the presence/absence binary perpetuated by the lesbian dildo wars, we take away the legitimation of the phallus altogether.

Smith (2002) finds that the dildo is useful in other forms beyond the submission/dominance model of sexual interaction. Citing the use of dildos in heterosexual sex, female masturbation, and the use of double dongs, she finds that the dominance/submission model does not account for the multitude of ways in which real people use the dildo for sexual pleasure. "Double dildos out each member of the couple simultaneously in the dominant and submissive position. In this instance, there is no clear masculinized dominant position" (p. 303). She argues,

Dildos are thus a terrific tool for learning by oneself or with one's partner about penetration without pain, or in fact, reconfiguring vaginal/penile intercourse as a taking in of the penis dildo, prompted by the woman's pace of receptivity rather than the penis/dildo's degree of force. (Smith, 2002, p. 307)

And here I stand at the intersection of these discourses, which attempt to frame sexual acts within different theoretical strains. My use of the dildo stands for so many varying positions. According to the radical/cultural separatists, I am only a reinvention of the heteronormative frame. When I/we/she insert(s) our dildo into her/my/our vagina, I am inscribing culturally male dominance from between my sheets outward to a larger population. To the sexual outlaws, I am enacting "real" lesbian sex acts, powerful, gritty, and raw. To Hamming (2001), I am a cyborg fucking with prosthesis, and I am powerful because I can put it on and take it off. During this 
sexual act, I am posthuman and free to fuck anyway I please. But to Smith, if I/we pay attention to a woman's agency and desire in sexual relations, however shifting and complex, we as feminists may be able to alter the way we understand the phallus.

Definition 4: Penetration ${ }^{5}$

The ability to make way into or through something

My lover, she is armor. Her brown hair tousled, her smile quirky. She pulls the straps of the harness tight. "Don't look at my butt," she says as she moves toward the drawer where the lubricant is located. I pull my hands over my eyes. I peek through anyway. And she laughs. "I asked you not to look!"

"Sorry. Well, not really," I say as I open my legs a little wider. With one finger she smoothes the lube on the cock. It looks like a penis. It has the veins, the strange fake balls. When we bought it, she was uncomfortable with the idea of the dildo having balls.

"It looks too much like a dick," she said as she waved the plastic packaging in front of me.

"Well, do you see anything else in here you like?' I asked, just as an awkward looking man walked out of the back room/peep show area. This is taking too long.

"Naw. It's fine. Let's just get it." She pretends to hump the plastic container to make me laugh. "I just never had a strap-on with balls before."

The extra lube she smears into my vagina. She pulls her body to cover mine. I shutter and squeal. The dildo remains still. I lift my body to meet hers and move the dildo further inside me. I hug tight to her chest. My fingers scrape her back, and she answers in moans. She moves her hips, and I move mine. The dildo hard and strong does not waiver. Her breath. Her body. She does not move until I'm ready. I do not shudder or stutter my body back into the memory of his taking. Here, we are both agents of our own bodies. She lets me move. We move each other into and through our own rhythms. We are the act, the agent, the contextual thrust of desire and love.

\section{Shifting Meaning: Shifting Arousal}

I am a woman with a past full of sexual violence. These past experiences have inscribed onto and through my body male-dominance and pain. I have associated sexual penetration with grief and fear. I cannot write away these truths by reframing the dildo into a new discourse. Or perhaps I can. I am left with a multitude of questions, an influx of penetrative memories. I am also left with desire, not mechanics or posthuman sexual arousal. I need to connect 
emotionally to a sexual partner because my memories of penetration are violent; I hold onto the seductive, passionate, soft, erotic, and pleasurable. Following Smith's (2002) call to "Pay close attention to the methods that are working, instances where the phallus has changed and be in tune with what women desire in sexual relations and need from the feminist movement" (p. 309), I offer this reading of my dildo use juxtaposed against the sexual violence that I have experienced.

The dildo has reframed quite vividly the way that I experience and understand human connection through sexual acts. These sexual experiences have moved along with me, quickly. The process of writing about these experiences is difficult. I scour my memory for encounters with the dildo. I try and find the language that embodies trauma, enlightenment, theoretical ties, and the body. I, like Tami Spry (2006), embrace the performativeI, rupturing memories of rape and today's spectacular presence of the dildo. Fragments of my lived experiences collide with one another to tell a different story from one of phallic violence. "A performative-I positionality emphasizes this critical potential of interrupting dominant cultural narratives deployed upon bodies by retelling those narratives from the body itself subjected/assigned to those narratives" (Spry, 2006, p. 344). I hope this retelling of penetration and penetrative acts interrupts the larger cultural narrative of the phallic/penile masculine grip on sexual acts. I do not attempt to generalize my experiences into the larger world but offer the reader one rereading of the dildo through a revisiting of sexual violence. "In the spirit of dialogic engagement, the text resists 'closure' and offers comfort in the inconsistency and partiality of knowing" (p. 342).

I do not feel the same shame that I once did when I was penetrated. I know now, I am an agent of my own making. I write here to make sense of these juxtaposed experiences, the ones that complexify my understanding of penetration to further solidify my agency. Contextual elements contour the way that I understand the dildo both discursively and kinesthetically.

\section{Definition 5: Penetration ${ }^{6}$ \\ Clear or deep perception of a situation}

Do I need a dick with balls to feel this good? I doubt it. Have I ever really thought about the strap-on dildo representing the penis? Maybe. I don't know. Let me see. I've never really looked at a strap-on before. I walk to my bedroom and take the dildo out of the drawer. The black straps slap against my wrist as I carry it back into my office. Ha. Our dog, Rhyn, tries to grab it with her teeth. She thinks the dildo is a toy. "No. No. Rhyn. This isn't for you," I say. "It is our toy," I think as I pull back the office chair and sit down. 
The light tan latex color glares in the office light. I say out loud, "There is a strange hole in the latex. I wonder if the manufacturer made a slight mistake."

"No," Stephanie says to me. She lifts her head from her book. "Don't you remember? Rhyn bit it after we left it on the bed," she giggles.

"Why does she have to bite everything that smells like vagina?" I ask laughing. "She always goes for the crotches of our underwear and our jeans!"

"I taught her well. She's a good lesbian, isn't she?" Stephanie asks and grins.

There are awkward veins that protrude from its sides. They are the same color as the rest of the dildo. It doesn't really remind me of the hard penis, let alone a soft one. It's too fake and springy. It does resemble the penis. It even has the tip, the balls. But the balls don't move. The tip isn't soft, like baby's skin. It's hard, uncomforting. It's certainly not as vulnerable as the penis.

Is it phallic? The answer depends on the definition. Although Freud's work within psychoanalysis may categorize the dildo as a symbolic point in which to uncover repressed emotions and resistant action, a more current undertaking of analytic psychoanalysis based on Freud's work would engage such a symbol with intersubjective awareness and the human process of change (Yalom, 2002, p. 220). From this vantage point, the penis as a "have" and the vagina as a "have not," or neither/nor or both/and, is dependent on a host of psychological, cultural, and interpersonal factors. I can see how when I was raped, I became the passive, submissive body and he was the penetrator, the aggressor, the one with all the power. But I have moved past this moment. His memory does not hold the power it once did. Now, he is the memory I can deconstruct to refigure the way I understand my own body, the aching core of sexual agency that thrives between my legs.

The dildo may represent the erect penis, but does it hold all the cultural implications, that is, the ability to fertilize, white male privilege, or the ability to penetrate? Penetration, sure, but a dildo needs to have moving bodies separate from the dildo itself behind it. The dildo can't fertilize (even though my girlfriend and I are in the process of inventing one right now). The dildo is ours, not any man's. We use this power to our own advantage, to please each other and ourselves.

A prosthesis? Ok. I can see how Hamming (2001) would argue this. I can take it off and put it on. When it hangs from my crotch, I can feel it as part of me, but not all of me. If the postlesbian is no longer human, then we lose our human, fallible, pulsing desire. I argue that the dildo holds as much agency as the person who engulfs it and the person who handles it allows.

I lay the strap on down on the desk beside me. It's so lifeless without her, without me, without our bodies. The art of penetration is nothing without the intentions, the ideas, the lovers, the bodies, the breath, the moment of 
contact, the movement of release. Together, the dildo, my lover and I have saved my sexual prowess.

\section{Releasing Heteronormativity: Orgasmic Excess}

My integration of desire, penetration, and the dildo is an example of how my heightened, repetitive use of a symbol (phallus), which was coded as violent, actually releases the negative attributes of the symbol through my performance excess. Gender theorist such as Butler (2004), Halberstam (2005), Grosz (1994), and de Lauretis (1994) echo this transformation by advancing theory that presupposes that individual agency is the ability to perform beyond normative categories of gender, sex, and/or sexuality through rescripting these norms. The contours of my experience, as written on my body, allow me to penetrate or be penetrated with a dildo in what appears like a performance of historically heteronormative penetration, but in actuality is an action of sexual resignification.

Jose Esteban Munoz (1999) views this performative resignification through a lens of disidentification. Disidentification as a mode of performance is the "response to state and global power apparatuses that employ systems of racial, sexual, and national subjugation," through "managing and negotiating historical trauma and systemic violence" (Munoz, 1999, p. 161). Managing and negotiating take shape in aesthetic repetition of norms (in this case, heightened performance of penetration), to create an excess of such norms. Possibilities beyond the norms are interpolated out of the necessity to disperse the excess in a creation of new narratives. Such excess begins to dwarf old narratives, thereby minimizing the oppressive power they once held. In other words, my continual enjoyment of dildo penetration, orgasm after orgasm with my girlfriend, offers release from damaging structures that support penetrative domination.

\section{Definition 6: Penetration}

Desire passed between, into, through, and with bodies.

Penetrative acts are not as violent as I once understood them to be. Rather penetration is a taking in, desire passed between, into, through, and with bodies. The definition of penetration shifts here and has shifted within my own body and mind. This makes all the difference. The dildo need not be a tool for scripting masculine hegemony. Rather, it has the potential to reshape penetration from a violent act into a powerful act of cocreation, involving both partners in consensual, connected desire. 
As a woman with a fluid sexual identity, I do not see my current sexual and loving relationship as some sort of sexual rebellion. I like men and women equally. I do not see my use of the dildo as a replacement for the penis but a supplement to the way my lover and I move our bodies together to orgasm. The phallus is my phallus. My performance of sexuality when I use a dildo is mine to choose. Similarly, when I take the dildo inside me, I perform my desire in a blend of sexual apprehension. I am the intersection of theories, not posthuman, nor outlaw, nor separatist. I reject the pressure of a heteronormative perspective, which attempts to box me into tight definitions of gender and sex performance. I am free to interpolate my own experience of moving identity in and outside of the bedroom, to include my use of a dildo with my partner. Now, when and if I encounter a penis or a new dildo, as a tool for sexual agency, I understand that the memory of violent penetration is just that, a memory.

I learned at an early age to associate the penis with the phallus and that it can be used without consent. Through resignification, the penetrative object is still phallic, but it is no longer a "stand-in man." My understanding of penetration has also shifted with my experiences with the dildo. When I bought my first dildo, I learned about my own sexual agency. In my first sexual encounter with a woman, I learned how memories of sexual violence penetrate just as violently as the original penis did. But I am able to transform my understanding of the penetrative act by reframing what a penetrative object is and can be. Now, the dildo offers an even fuller sense of sexual agency with my lover. She and I share power in these encounters and allow pleasure and play into the bedroom. Because of this, I realize that I am a sexual agent of my own making, passing desire between and through bodies. It's not the dildo. It's the person behind it and around it.

\section{Notes}

1. Our Bodies Our Selves

2. Wordreference.com

3. Wordreference.com

4. Wordreference.com

5. Wordreference.com

6. Wordreference.com

\section{References}

Allison, D. (1994). Skin: Talking about sex, class, and literature. Ithaca, NY: Firebrand Books. Bright, S. (1990). Susie sexpert's lesbian sex world. Pittsburgh, PA: Cleis. 
Butler, J. (2004). Undoing gender. New York: Routledge.

Califia, P. (1988). Macho sluts. Boston: Alyson.

Chodron, P. (2006). Practicing peace in times of war. Boston: Shambhala.

Congdon, T. (1997, September 22). Mrs. Coffin's consolidation. Forbes, 160, S69-S74.

de Lauretis, T. (1994). Practices of love: Lesbian sexuality and perverse desire. Bloomington: Indiana University Press.

Denzin, N., \& Lincoln, Y. (2000). Handbook of qualitative research (2nd ed.). Thousand Oaks, CA: Sage.

Dworkin, A. (1981). Pornography: Men possessing women. New York: Putnam.

Edgar, A., \& Sedgwick, P. (Eds). (1999). Key concepts in cultural theory. New York: Routledge.

Findlay, H. (1992). Freud's fetishism and the lesbian dildo debates. Feminist Studies, 18, 563-579.

Grosz, E. (1989). Sexual subversions: Three French feminists. Sydney, New South Wales, Australia: Allen \& Unwin.

Grosz, E. (1994). Refiguring lesbian desire. In L. Doan (Ed.), The lesbian postmodern (pp. 67-84). New York: Columbia University Press.

Halberstam, J. (2005). In a queer time and place: Transgender bodies, subcultural lives. New York: New York University Press.

Hamming, J. E. (2001). Dildonics, dykes, and the detachable machine. European Journal of Women's Studies, 8, 329-341.

Haraway, D. J. (1991). Simians, cyborgs, and women: The reinvention of nature. New York: Routledge.

hooks, bel. (2000). Feminism is for everybody: Passionate politics. Cambridge, MA: The South End Press Collective.

Johnston, J. (1973). Lesbian nation: The feminist solution. New York: Simon \& Schuster.

Kennedy, K. (2000). Writing trash: Truth and the sexual outlaw's reinvention of lesbian identity. Feminist Theory, 1, 151-172.

Kincheloe, J. L. (2001). Describing the bricolage: Conceptualizing a new rigor in qualitative research. Qualitative Inquiry, 7, 679-692.

Maines, R. (1999). The technology of orgasm: Hysteria, the vibrator, and women's sexual satisfaction. Baltimore: Johns Hopkins University Press.

MacKinnon, C. A. (1986). Pornography as sex discrimination. Law and Inequality, 4, 38-49.

Minge, J. M. (2007). The stained body: A fusion of embodied art on rape and love. Journal of Contemporary Ethnography, 36, 252-280.

Munoz, J. E. (1999). Disidentification: Queers of color and the performance of politics. Minneapolis: University of Minnesota Press.

Nestle, J. (1987). A restricted country. Ithaca, NY: Firebrand Books.

Potts, A. (2000). The essence of the hard on: Hegemonic masculinity and the cultural construction of erectile dysfunction. Men and Masculinities, 3, 85-103.

Rich, A. (1980). The dream of a common language. New York: W. W. Norton.

Rich, A. (1984). Compulsory heterosexuality and lesbian existence. In T. Darty \& S. Potter (Eds.), Women-identified women (pp. 119-148). Palo Alto, CA: Mayfield.

Rich, A. (2001). Arts of the possible. New York: W. W. Norton.

Richardson, L. (2000). Writing: A method of inquiry. In N. Denzin \& Y. Lincoln (Eds.), Handbook of qualitative research (pp. 923-948). Thousand Oaks, CA: Sage.

Rubin, G. (1987). The leather menace: Comments on politics and S/M. In Samois (Ed.), Coming to power: Writings and graphics on lesbian S/M (pp. 194-229). Boston: Alyson. 
Shay, J. (1994). Achilles in Vietnam: Combat trauma and the undoing of character. New York: Touchstone.

Smith, S. (2002). A cock of one's own. In M. L. Johnson (Ed.), Jane sexes it up: True confessions of feminist desire (pp. 293-310). New York: Four Walls Eight Windows.

Spry, T. (2006). A performative-I copresence: Embodying the ethnographic turn in performance and the performative turn in ethnography. Text and Performance Quarterly, 26, 339-346.

Tillmann-Healy, L. M. (1996). A secret in a culture of thinness: Reflections on body, food, and bulimia. In C. Ellis \& A. P. Bochner (Eds.), Composing ethnography: Alternative forms of qualitative writing (pp. 76-108). Walnut Creek, CA: Sage.

Yalom, I. D. (2002). The gift of therapy: An open letter to a new generation of therapists and their patients. New York: Harper Collins.

Jeanine Marie Minge ( $\mathrm{PhD}$, University of South Florida) is an Assistant Professor at the University of California, Northridge. Her areas of interest include performance studies, feminist theory, queer theory, community art, and arts-based inquiry. Correspondence regarding this essay may be addressed to the author at jeanine.minge@gmail.com.

Amber Lynn Zimmerman ( $\mathrm{PhD}$, Southern Illinois University) is an Assistant Professor at the University of Waterloo in Ontario, Canada. Her research includes feminism, sexuality, spirituality, and performance art. Correspondence regarding this essay may be addressed to the author at alzimmer@uwaterloo.ca. 